\title{
ANALISIS KINERJA KARYAWAN PADA PT. BANK MANDIRI (PERSERO), Tbk. CABANG CENDRAWASIH MAKASSAR
}

\section{ANALYSIS OF EMPLOYEE PERFORMANCE IN PT. BANK MANDIRI (PERSERO), Tbk. CENDRAWASIH MAKASSAR BRANCH}

\author{
Gadis Ayu Putri Gayatri ${ }^{1}$, Amir Imbaruddin ${ }^{2}$, Muttaqin ${ }^{3}$ \\ ${ }^{1}$ Call Center pt. Bank Mandiri (Persero) Tbk. Cabang Cendrawasih Makassar \\ e-mail: gadisayuputrigayatri@gmail.com \\ ${ }^{2}$ Sekolah Tinggi Ilmu Administrasi Lembaga Administrasi Negara Makassar \\ e-mail : aimbaruddin@yahoo.com \\ ${ }^{3}$ Sekolah Tinggi Ilmu Administrasi Lembaga Administrasi Negara Makassar \\ e-mail : muttaqin_lan@yahoo.com
}

\begin{abstract}
Abstrak
Era globalisasi sekarang ini menuntut perusahaan untuk selalu menyesuaikan strateginya dengan perubahan yang terjadi agar tetap bisa bertahan hidup atau menjamin kontinuitas perusahaan. Untuk menjamin kelangsungan hidup suatu perusahaan maka salah satu asset paling berharga yang dimiliki oleh suatu perusahaan adalah sumber daya manusia. Sumber daya manusia merupakan peran utama dalam setiap kegiatan perusahaan. Walaupun banyaknya sarana dan prasarana, tanpa dukungan sumber daya manusia maka kegiatan perusahaan tidak akan berjalan dengan baik. Untuk mencapai tujuan perusahaan, maka karyawan dituntut untuk memaksimalkan kinerja yang dimiliki. Tujuan penelitian ini adalah untuk mengetahui dan menganalisis bagaimana penilaian kinerja karyawan pada PT. Bank Mandiri (Persero) Tbk. Cabang Cendrawasih Makassar, dengan pendekatan kualitatif, dan menggunakan instrumen melalui wawancara, observasi dan telaah dokumen. Sedangkan teknik pengumpulan data melalui wawancara, observasi dan telaah dokumen. Teknik pengolahan data dengan menggunakan analisis deskriptif. Hasil penelitian bahwa karyawan dalam menyelesaikan pekerjaan rata-rata sudah bekerja sesuai dengan yang ditargetkan dan sudah mampu meningkatkan pencairan kredit. Ditinjau dari aspek kualitas pekerjaan, masih rendahnya tingkat kesalahan dalam menyelesaikan pekerjaan dan selain itu setiap karyawan dalam menyelesaikan pekerjaan sesuai dengan yang ditentukan. Ditinjau dari aspek ketepatan waktu, karyawan telah memiliki kemampuan dalam menyelesaikan setiap pekerjaan secara tepat waktu. Ditinjau dari aspek kehadiran, bahwa tingkat kehadiran karyawan yang relatif tinggi karena karyawan tepat waktu masuk kantor Sedangkan ditinjau dari kemampuan kerjasama. Dimana dalam penelitian ini diperoleh temuan bahwa karyawan dalam melakukan pekerjaan selalu menjalin kerjasama dengan rekan kerja lainnya dan selain itu adanya tim kerja serta adanya jalinan hubungan yang baik antara atasan dengan bawahan.
\end{abstract}

Kata kunci: Jumlah pekerjaan, kualitas pekerjaan, ketepatan waktu, kehadiran dan kemampuan kerjasama 


\begin{abstract}
The current era of globalization requires companies to always adjust their strategies to changes that occur in order to survive or guarantee the continuity of the company. Human resources are the main role in every company activity. Despite many facilities and infrastructures, without the support of human resources, the company's activities will not run well. To achieve company goals, employees are required to maximize their performance. The purpose of this study was to determine and analyze how employee performance appraisal at PT. Bank Mandiri (Persero) Tbk. Cendrawasih Makassar Branch, with a qualitative approach, and using instruments through interviews, observation and document review. While data collectiotechniques are through interviews, observation and document review. Data processing technique is descriptive analysis. The result of the study shows that most employees finish their work based on the estimated targets and are capable to increase the demand of loan credit. Judging the aspect of the quality of the work, the level of error in completing the work is still low and besides that, each employee complete the work according to the specified objectives. Judging from the timeliness aspect, employees have the ability to complete each job in a timely manner. Judging the aspect of attendance, that employee attendance is relatively high because employees attend the office on time. While in terms of the ability to cooperate, this study found that employees in doing work always establish cooperation with other colleagues and collaborate in a teamwork and maintain good relationship between superiors and subordinates.
\end{abstract}

Keywords: total work done, quality of work, timeliness, attendance and ability to cooperate

\section{PENDAHULUAN}

Semakin tajam persaingan pada era globalisasi sekarang ini menuntut perusahaan untuk selalu menyesuaikan strateginya dengan perubahan yang terjadi agar tetap bisa bertahan hidup. Sumber daya manusia mempakan peran utama dalam setiap kegiatan perusahaan. Walaupun banyaknya sarana dan prasarana serta sumber daya, tanpa dukungan sumber daya manusia maka kegiatan perusahaan tidak akan berjalan dengan baik. Dengan demikian sumber daya manusia merupakan kunci pokok yang harus diperhatikan dalam segala kebutuhannya. Sebagai kunci pokok, sumber daya manusia akan menentukan keberhasilan pelaksanaan kegiatan perusahaan. Tuntutan perusahaan untuk memperoleh mengembangkan dan mempertahankan sumber daya manusia yang berkualitas (Ambar dan Rosidah, 2013).
Untuk mencapai tujuan perusahaan, tentunya karyawan dituntut untuk memaksimalkan kinerja yang dia miliki. Kinerja karyawan sebagai kemampuan karyawan dalam melakukan sesuatu keahlian tertentu (Sinambella, 2012). Kinerja seseorang merupakan ukuran sejauh mana keberhasilan seseorang dalam melakukan tugas pekerjaannya. Kinerja karyawan diartikan sebagai pencapaian tugas, dimana karyawan dalam bekerja harus sesuai dengan program kerja organisasi untuk menunjukkan tingkat kinerja organisasi dalam mencapai visi, misi, dan tujuan organisasi (Hakim, 2014)

Untuk menentukan kinerja karyawan baik atau tidak, tergantung pada hasil perbandingannya dengan standar pekerjaan, karena kinerja merupakan gambaran mengenai tingkat pencapaian pelaksanaan suatu kegiatan atau program atau kebijakan dalam 
mewujudkan sasaran, tujuan, misi dan visi organisasi yang tertuang dalam strategic planning (Sembiring, 2012).

Seorang karyawan dikatakan berhasil melaksanakan pekerjaannya atau memiliki kinerja baik, apabila hasil kerja yang diperoleh lebih tinggi dari standar kinerja. Untuk mengetahui hal itu perlu dilakukan penilaian kinerja setiap karyawan dalam perusahaan. Pengukuran atau penilaian kinerja (performance measurement) mempunyai pengertian suatu proses penilaian tentang suatu kemajuan pekerjaan terhadap tujuan dan sasaran dalam pengelolaan sumber daya manusia untuk menghasilkan barang dan jasa termasuk informasi atas efisiensi serta efektifitas tindakan dalam mencapai tujuan organisasi (Moeheriono, 2012).

Untuk memudahkan dalam penilaian kinerja karyawan, standar pekerjaan harus dapat diukur dan dipahami secara jelas. Untuk mengukur kinerja karyawan maka terdapat beberapa hal yang perlu diperhatikan menurut Bangun (2012) bahwa jumlah pekerjaan, kualitas pekerjaan, ketepatan waktu, kehadiran dan kemampuan kerja sama.

Penelitian ini dilakukan pada PT. Bank Mandiri (Persero), Tbk. Cabang Cendrawasih Makassar. Bank Mandiri merupakan salah satu bank terkemuka yang terdapat di Indonesia. Bank Mandiri merupakan hasil merger dari empat bank yang terdapat diIndonesia yaitu Bank Bumi Daya, Bank Dagang Negara, Bank
Pembangunan Indonesia dan Bank Expor Impor.

Permasalahan yang dihadapi saat ini bahwa kinerja karyawan bagian kredit menurun, dilihat dari data target dan realisasi bagian marketing yang berisi data bade, booking NPL, serta persentasi pencapaian kinerja penjualan marketing dari bulan Juli s/d bulan Desember tahun 2017 nampak terjadi penurunan kinerja bagian marketing, dimana rata-rata bagian marketing tidak mencapai target yang telah ditentukan oleh PT. Bank Mandiri Cabang Cendrawasih. Selain itu bahwa masyarakat atau nasabah sering mengeluh terhadap pelayanan yang diberikan terkesan lambat serta sering terjadi jaringan yang offline.

\section{METODE PENELITIAN}

Pendekatan yang digunakan dalam penelitian ini adalah dengan menggunakan pendekatan penelitian deskriptif/kualitatif, yakni penelitian yang sangat relevan digunakan karena dalam penelitian ini peneliti ingin mengkaji lebih dalam dari beberapa fenomena yang terjadi pada perusahaan PT. Bank Mandiri Cabang Cendrawasih terkait dengan kinerja karyawan.

Untuk memudahkan dalam peneli-tian ini maka peneliti menggunakan se-jumlah informan pada PT. Bank Mandiri (Persero) Tbk. Cabang Cendrawasih Makassar, dimana yang menjadi unit informan. Peneliti melakukan wawancara terhadap sejumlah 
informan yang telah ditentukan yakni, Pimpinan Cabang, Kepala bagian Personalia, Staf Bagian Personalia, Karyawan dan Karyawan Bagian Marketing yang bekerja pada PT. Bank Mandiri (Persero) Tbk. Cabang Cendrawasih Makassar, oleh sebab itu maka yang menjadi informan ditentukan sebanyak 2 orang informan yakni Hendri dan Narwiyah. Pemilihan kedua informan ini dengan pertimbangan bahwa Informan Henri dan Narwiyah merupakan staf personalia pada PT. Bank Mandiri Cabang Cendrawasih Makassar yang mengetahui dengan jelas mengenai perbankan khususnya marketing bagian kredit.

Kemudian teknik pengumpulan data merupakan langkah-langkah dalam mendapatkan data, yang terdiri dari wawancara yaitu suatu cara pengumpulan data yang digunakan oleh peneliti untuk memperoleh informasi dengan tanya jawab secara lisan dan tatap muka dengan responden. Pedoman wawancara ini berisi pertanyaan dalam kuesioner yang dilakukan secara lisan dan bertatap muka secara langsung kepada responden dalam hal ini adalah karyawan pada PT. Bank Mandiri (Persero) Tbk. Cabang Cendrawasih. Kemudian observasi yaitu melakukan pengamatan secara langsung terhadap objek penelitian. Telaah Dokumen yakni mengumpulkan dan mempelajari data yang relevan dan mendukung penelitian, kepustakaan, bahan-bahan kuliah, teori para ahli, serta dokumen atau arsip-arsip dari perusahaan yang mendukung penelitian ini.

Penelitian dan pengolahan data yang dilakukan yaitu dengan menggunakan analisa kualitatif dengan langkah-langkah yang digunakan sebagai berikut. Tahap pengumpulan data, reduksi data, diartikan sebagai proses pemilihan, pemusatan perhatian pada penyederhanaan, peng-abstrakan, dan transformasi data kasar yang muncul dari catatancatatan di lapangan. Kegiatan reduksi data sangat penting karena yang bersangkutan dapat mulai memilih data mana yang data dari siapa yang dipertajam, data yang tidak sesuai atau data yang tidak relevan dengan tema penelitian. Display data, langkah berikutnya setelah proses reduksi data berlangsung adalah penyajian data, sebagai sekumpulan informasi tersusun yang memberi kemungkinan adanya penarikan kesimpulan dan pengambilan tindakan. Verifikasi, yaitu penguatan data yang diupayakan oleh peneliti dengan melakukan triangulasi data untuk mendeskripsikan secara rinci tentang hasil penelitian yang dilaksanakan, dengan tetap mengacu pada fokus penelitian, serta penarikan kesimpulan, yaitu peneliti mengambil kesimpulan setelah membahas hasil penelitian atau setelah melalui tahapan tersebut di atas maka ditarik suatu kesimpulan merupakan hasil yang akan dicapai. 


\section{HASIL PENELITIAN}

Kinerja karyawan merupakan hasil atau tingkat keberhasilan seseorang secara keseluruhan selama periode tertentu dalam pelaksanaan tugas dibandingkan dengan target atau sasaran dan kriteria suatu kinerja karyawan, khususnya di sektor perbankan. Sebab keberhasilan seorang karyawan dalam bekerja sangat ditentukan oleh adanya hasil kerja yang dicapai dalam kegiatan penyelesaian pekerjaan. Dimana dalam menjalankan aktivitasnya maka perlu ditunjang oleh adanya kinerja karyawan, sebab dengan kinerja karyawan maka akan mempengaruhi tujuan dan sasaran yang telah ditentukan oleh Bank Mandiri, sehingga kinerja karyawan dapat dinilai dengan 5 aspek yaitu, jumlah pekerjaan, kualitas pekerjaan, ketepatan waktu, kehadiran dan kemampuan kerja sama.

\section{Analisis Jumlah Pekerjaan}

Analisis kinerja karyawan ditinjau dari aspek jumlah pekerjaan, berkaitan dengan analisis target yang dicapai. Berdasarkan data kinerja bank Mandiri Cabang Cendrawasih nampak bahwa secara keseluruhan bank Mandiri Cabang Cendrawasih sudah memiliki kinerja yang baik, hal ini dapat dilihat bahwa karyawan dalam melakukan pekerjaan selalu diberikan target dalam penyelesaian pekerjaan, guna dapat dijadikan sebagai ukuran keberhasilan karyawan dalam penyelesaian pekerjaan.
Kemudian ditinjau dari analisis jumlah bagian Marketing nampak bahwa dalam menunjang pelayanan nasabah untuk kegiatan pemberian kredit kepada nasabah maka jumlah tenaga marketing yang digunakan ada 7 orang yang tersebar pada Makassar Cendrawasih 1 dan Makassar Cendrawasih 2. Selain itu masa kerja tenaga marketing yang terlibat langsung dalam melakukan pekerjaan pencairan kredit terlihat memiliki masa kerja antara 4-5 tahun sehingga hal ini yang menjadi dampak bahwa pelaksanaan pekerjaan pencairan kredit pada PT. Bank Mandiri (Persero), Tbk. Cabang Cendrawasih Makassar sesuai dengan yang direalisasikan.

\section{Analisis Kualitas Pekerjaan}

Kinerja karyawan ditinjau dari aspek kualitas pekerjaan melalui analisis tingkat kesalahan, dimana dari hasil observasi yang dilakukan nampak bahwa karyawan Bank Mandiri sangat kecil dalam melakukan kesalahan dalam bekerja, hal ini disebabkan karena adanya keterlibatan pimpinan dalam memberikan instruksi kerja mengenai cara mengerjakan dan menyelesaikan suatu pekerjaan. Adapun kesalahan yang sering dilakukan bersifat kecil seperti lupa meminta identitas nasabah ketika ada klaim, Salah BI Cheking saat ada yang pengajuan kredit, Surat keterangan usaha palsu serta tidak melakukan konfirmasi tetangga sekitar usaha.

Kemudian dilihat dari analisis melakukan pekerjaan sesuai ketentuan, nam- 
pak bahwa karyawan bank Mandiri sudah cermat dalam melakukan pekerjaan sudah mengikuti ketentuan yang telah ditetapkan, alasannya karena sudah menggunakan Standar Operasional Prosedur (SOP) yang telah dibuat oleh PT. Bank Mandiri (Persero), Tbk. Cabang Cendrawasih Makassar Nomor X.MKS. RHC/992/2013 mengenai pemberian job desk pegawai, keterangan pelaksanaan cuti pegawai dan Peraturan Disiplin Pegawai terkait dengan peraturan kehadiran dan jam kerja pegawai. Dari data hari kerja, jam kerja dan absensi sesuai dengan nomor: X. MKS.RHC/992/2013 menunjukkan bahwa karyawan bagian marketing sudah menggunakan Standar Operasional Prosedur (SOP) sebagai acuan atau pedoman sehingga dapat menyelesaikan pekerjaan sesuai dengan waktu yang telah ditentukan.

\section{Analisis Ketepatan Waktu}

Analisis ketepatan waktu ditinjau dari analisis melakukan pekerjaan sesuai dengan deadline dapat dilihat data marketing yang melakukan pengurusan kredit bagi setiap nasabah sudah menyelesaikan pekerjaan sesuai dengan deadline, hal ini dapat dilihat dari data jumlah nasabah melakukan pembayaran kredit sudah termasuk dalam kategori lancar dari bulan Juli s/d bulan September 2017, bahwa data jumlah nasabah yang mengambil kredit, terlihat bahwa rata-rata nasabah aktif dalam melakukan pembayaran kredit yakni di atas dari $80 \%$, termasuk dalam kategori nasabah tidak lancar atau netral yakni di bawah dari
$14 \%$, sedangkan nasabah yang termasuk dalam kategori pembayaran kredit macet yakni sudah dibawah dari $8 \%$.

Kemudian ditinjau dari indikator analisis kinerja dengan memanfaatkan waktu senggang, dimana dengan meman-faatkan waktu luang maka pekerjaan yang tertunda dapat diselesaikan sesuai dengan waktu yang telah ditentukan. Ini menun-jukkan bahwa karyawan yang bekerja pada PT. Bank Mandiri (Persero), Tbk. Cabang Cendrawasih selalu memanfaatkan waktu luang atau jam istirahat untuk menyelesaikan pekerjaan, karena karyawan bagian marketing selalu sibuk di lapangan dalam mencari nasabah kredit, serta melakukan penagihan kredit sehingga tidak ada waktu untuk melakukan pencatatan, oleh karena itu di waktu-waktu istirahat atau luang maka bagian marketing memanfaatkan waktu istirahat untuk menyelesaikan pekerjaan.

Selanjutnya analisis kinerja karyawan ditinjau dari aspek kehadiran merupakan aspek yang penting dalam pelaksanaan pekerjaan melalui analisis datang tepat waktu masuk kantor, hasil observasi bahwa ketepatan waktu masuk kantor karyawan dalam bekerja sudah dianggap baik, karena didukung dengan surat peraturan jam kerja karyawan dengan No. X.MKS. RHC/992/2013 ditetapkan bahwa jam kerja karyawan antara 07.30-16.30 (waktu setempat), dengan hari kerja yakni hari SeninJumat atau 5 hari kerja seminggu, dengan waktu istirahat antara jam 12.00-13.00 (waktu 
setempat/maksi-mal 1 jam). Adapun sarana yang diguna-kan dalam mengabsensi karyawan adalah Handkey Machine, Finger Print, Kartu Amano atau Tanda Tangan pada Buku Daftar Hadir. Dari hasil observasi yang dilakukan bahwa PT. Bank Mandiri (Persero) Tbk. Cabang Cendrawasih Makassar menggunakan mesin absensi Fringer Print, yakni dengan menempelkan sidik jari ke dalam mesin Fringer print maka pelaksanaan absensi yang dilakukan oleh karyawan selesai.

Kemudian dilihat dari aspek melakukan pekerjaan sesuai dengan waktu yang ditentukan, nampak bahwa tingkat kehadiran karyawan sudah berjalan dengan baik sehingga mempengaruhi ketepatan waktu dalam menyelesaikan pekerjaan. Hal ini didukung dengan data absensi karyawan yang sudah baik, ini disebabkan karena adanya sanksi yang diberikan jika pegawai melakukan pelanggaran sebagaimana tercantum pada dokumentasi mengenai pemberian job desk pegawai No. X/MKS.RH/ 992/2013 berisikan:

\section{TABEL 1}

Jenis Sanksi dan Jenis Pelanggaran

\begin{tabular}{|l|ll|}
\hline Jenis Sanksi & \multicolumn{1}{|c|}{ Jenis Pelanggan } \\
\hline $\begin{array}{l}\text { 1. Pembinaan } \\
\text { dengan Beri- } \\
\text { ta Acara }\end{array}$ & a. & $\begin{array}{l}\text { Pegawai lupa absen } \\
\text { dan/atau }\end{array}$ \\
& b. $\begin{array}{l}\text { Datang terlambat (DT) } \\
\text { dan/atau }\end{array}$ \\
c. $\begin{array}{l}\text { Pulang cepat (PC) lebih 3 } \\
\text { (tiga) kali dalam satu } \\
\text { bulan }\end{array}$ \\
\hline $\begin{array}{l}\text { 2. Sanksi } \\
\text { jenis ringan } \\
\text { pertama }\end{array}$ & a. $\begin{array}{l}\text { Jika pelanggaran pada } \\
\text { butir diulang kembali }\end{array}$ \\
\hline
\end{tabular}

\begin{tabular}{|c|c|}
\hline & hari dalam satu bulan \\
\hline $\begin{array}{l}\text { 3. Sanksi } \\
\text { jenis ringan } \\
\text { kedua }\end{array}$ & $\begin{array}{ll}\text { a. } & \text { Jika pelanggaran butir } \\
\text { diulang kembali setelah } \\
\text { mendapat sanksi jenis } \\
\text { ringan pertama pada butir } \\
2 \text { di atas, atau } \\
\text { b. Jika pegawai mangkir } 2 \\
\text { hari yang tidak berturut- } \\
\text { turut dalam satu bulan } \\
\end{array}$ \\
\hline $\begin{array}{l}\text { 4. Sanksi } \\
\text { jenis Sedang }\end{array}$ & 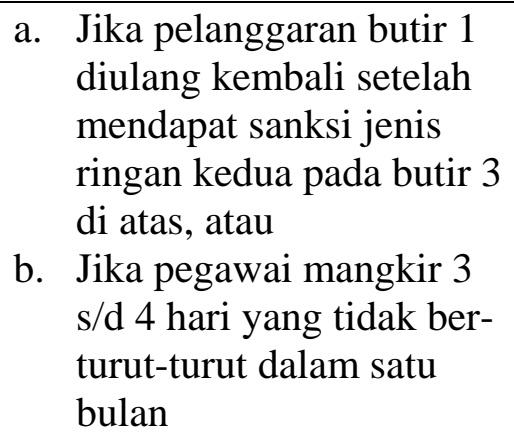 \\
\hline
\end{tabular}

Sumber: Data dokumentasi mengenai pemberian job desk pegawai No. X/MKS. RH/992/2013

\section{Analisis Kerjasama}

Salah satu aspek mengenai kinerja karyawan pada PT. Bank Mandiri (Persero), Tbk. Cabang Cendrawasih ada-lah aspek kerja sama. Kerja sama merupa-kan bagian yang terpenting dalam melaku-kan pekerjaan yang ada pada kegiatan perbankan, sehingga dengan pentingnya kerja sama antara karyawan dalam bank maka perlu dilakukan penilaian kinerja karyawan ditinjau dari aspek kerja sama pada PT. Bank Mandiri (Persero), Tbk. Cabang Cendrawasih Makassar terlihat bahwa setiap tim kerja dalam menjalankan aktivitas pekerjaan sehari-hari selalu bekerja sama dengan rekan kerja lainnya sehingga penyelesaian pekerjaan dapat diselesaikan secara tepat waktu. Selain itu senantiasa terjalin hubungan kerja sama yang harmonis antara atasan dengan bawahan, serta melakukan pemben- 
tukan tim atau kelompok untuk memudahkan dalam penyelesaian pekerjaan.

Sedangkan ditinjau dari aspek kontribusi karyawan dengan nasabah (debitur) menunjukkan bahwa rekan kerja selalu memberikan kontribusi dalam pe-nyelesaian pekerjaan sehingga mempenga-ruhi hasil kerja yang ada pada PT. Bank Mandiri (Persero), Tbk. Cabang Cendrawasih Makassar. Antara nasabah dengan karyawan bagian marketing selalu memberikan kontribusi dalam pelaksanaan pekerjaan dimana karyawan selalu saling bantu membantu dalam menyelesaikan pekerjaan untuk membantu nasabah dalam pemberian informasi mengenai akad kredit, sehingga nasabah yang ingin mengambil kredit ataupun nasabah yang ingin melanjutkan kredit dapat berjalan sesuai dengan kebutuhan nasabah. Sesuai dengan data manual produk kredit mikro No. 005/KRD/ MRB. MBD/ 2017 tanggal 28 Agustus 2017 terkandung persyaratan bagi debitur baru dan debitur lama yang ingin mengambil kredit lagi, dan ini merupakan tugas bagian marketing dalam memberikan informasi dan arahan-arahan kepada nasabah yang akan mengambil kredit, sehingga ada kontribusi antara karyawan bagian marketing dalam mencapai target dengan nasabah yang memerlukan kebutuhan kredit.

\section{PEMBAHASAN}

Hasil analisis ini menunjukkan bahwa analisis kinerja karyawan ditinjau dari aspek jumlah pekerjaan, kualitas pekerjaan, ketepatan waktu, kehadiran dan kemampuan kerjasama sudah berjalan sesuai dengan yang diharapkan oleh perusahaan sebagaimana yang dikemukakan oleh Bangun (2012) bahwa kinerja karyawan dapat ditinjau dari beberapa aspek yakni jumlah pekerjaan, kualitas pekerjaan, ketepatan waktu, kehadiran dan kemampuan kerja sama.

\section{Jumlah Pekerjaan}

Hasil analisis kinerja karyawan ditinjau dari aspek jumlah pekerjaan menunjukkan hasil pekerjaan yang dicapai oleh karyawan selama ini. Dimana salah satu aspek dalam penilaian kinerja pegawai adalah berkaitan dengan jumlah pekerjaan yang dilakukan selama ini yakni dengan kemampuan karyawan dalam mencapai target yang telah ditentukan oleh pimpinan perusahaan PT. Bank Mandiri (Persero), Tbk. Cabang Cendrawasih. Dimana dari hasil pencapaian target pengelolaan pekerjaan sudah sesuai dengan yang ditargetkan. Hal ini dapat dilihat dari penyelesaian pekerjaan pada PT. Bank Mandiri (Persero), Tbk. Cabang Cendrawasih terlihat bahwa tenaga marketing sudah memiliki kompetensi dalam menyelesaikan pekerjaan yang dilakukan selama ini.

\section{Kualitas Pekerjaan}

Kualitas pekerjaan yang dicapai oleh karyawan pada perusahaan PT. Bank Mandiri (Persero), Tbk. Cabang Cendrawasih sudah tergolong baik, hal ini sesuai hasil wawancara yang telah dilakukan bahwa tingkat kesalahan 
yang terjadi saat karyawan PT. Bank Mandiri (Persero), Tbk. Cabang Cendrawasih melakukan pekerjaan selama ini masih tergolong rendah. Dimana karyawan dalam melakukan pekerjaan sudah memiliki ketelitian dan kecermatan dalam menangani setiap pekerjaan yang dilakukan selama ini. Kemudian hasil analisis mengenai pelaksanaan pekerjaan yang dilakukan selama ini, dimana setiap pekerjaan yang ditangani oleh karyawan sudah sesuai dengan ketentuan yang ditentukan oleh atasan pada PT. Bank Mandiri (Persero), Tbk. Cabang Cendra-wasih, alasannya karena setiap pekerjaan yang akan dikerjakan harus sesuai dengan SOP yang telah ditetapkan.

\section{Ketepatan Waktu}

Ketepatan waktu dalam pelaksa-naan pekerjaan menjadi faktor yang dapat mempengaruhi kinerja karyawan pada PT. Bank Mandiri (Persero), Tbk. Cabang Cendrawasih. Dimana hasil penyelesaian pekerjaan sesuai dengan deadline, hal ini menunjukkan bahwa pelaksanaan peker-jaan selalu dilakukan secara tepat waktu, karena sudah ada jadwal pelaksanaan kerja yang dibuat oleh masing-masing karyawan dalam menangani pekerjaan. Kemudian pemanfaatan waktu yang digunakan oleh masing-masing karyawan saat ini sudah tergolong baik. Alasannya karena karyawan pada perusahaan PT. Bank Mandiri (Persero), Tbk. Cabang Cendrawasih sudah mampu memanfaat-kan waktu dalam menyelesaikan pekerjaan sehingga mempengaruhi peningkatan kinerja karyawan.

\section{Kehadiran}

Ditinjau dari aspek tingkat kehadi-ran karyawan pada PT. Bank Mandiri (Persero), Tbk. Cabang Cendrawasih selama ini sudah dikategorikan baik, hal ini dapat dilihat dari tingkat kehadiran karyawan sudah tergolong baik sebab PT. Bank Mandiri (Persero), Tbk. Cabang Cendrawasih telah menggunakan mesin absensi Fringer print yang tergolong praktis dan sangat mudah digunakan sehingga tidak ada bentuk penyelewengan mengenai data absensi. Sehingga dengan menggunakan mesin absensi maka karyawan selalu datang tepat waktu masuk kantor dan pulang kantor. Kemudian dengan tingkat kehadiran karyawan yang tergolong baik pada PT. Bank Mandiri (Persero), Tbk. Cabang Cendrawasih selama ini maka dalam melakukan pekerjaan setiap karyawan yang bekerja sudah menyelesaikan pekerjaan sesuai dengan waktu yang telah ditentukan.

\section{Kerjasama}

Analisis kinerja karyawan ditinjau dari aspek kerjasama nampak bahwa masingmasing karyawan pada PT. Bank Mandiri (Persero), Tbk. Cabang Cendrawasih selalu melakukan kerjasama dengan sesama rekan kerja lainnya, sehingga pekerjaan yang diberikan dapat diselesaikan secara tepat waktu serta sesuai dengan target yang ditentukan. 
Kemudian upaya dalam meningkatkan kelancaran penyelesaian pekerjaan maka selalu dibentuk tim kerja guna menunjang kelancaran aktivitas kerja sehari-hari pada PT. Bank Mandiri (Persero), Tbk. Cabang Cendrawasih. Hubungan antara atasan dengan bawahan yang dilakukan selama ini sudah berjalan dengan baik, dimana atasan senantiasa memberikan pengarahan kepada karyawan bank Mandiri dalam menyelesaikan pekerjaan, serta rekan kerja sudah mampu memberikan kontribusi dalam menyelesaikan pekerjaan.

\section{KESIMPULAN DAN SARAN}

Kinerja karyawan ditinjau dari aspek jumlah pekerjaan terlihat bahwa karyawan dalam menyelesaikan pekerjaan rata-rata sudah bekerja sesuai dengan yang ditargetkan dan selain itu jumlah karyawan bagian marketing sudah mampu meningkatkan pencairan kredit karena didukung oleh pengetahuan, keahlian, dan masa kerja yang dimiliki oleh setiap pegawai dalam menyelesaikan pekerjaan. Kemudian dari hasil analisis mengenai kinerja karyawan pada PT. Bank Mandiri (Persero), Tbk. Cabang Cendrawasih ditinjau dari aspek kualitas pekerjaan, hal ini dapat dkatakan bahwa masih rendahnya tingkat kesalahan dalam menyelesaikan pekerjaan dan selain itu setiap karyawan dalam menyelesaikan pekerjaan sesuai dengan yang ditentukan. Hasil analisis mengenai kinerja karyawan pada PT. Bank Mandiri (Persero), Tbk. Cabang Cendrawasih ditinjau dari aspek ketepatan waktu, terlihat bahwa karyawan telah memiliki kemampuan dalam menyelesai-kan setiap pekerjaan secara tepat waktu dan selain karyawan senantiasa memanfaatkan waktu dalam menyelesai-kan pekerjaan. Hasil analisis mengenai kinerja karyawan pada PT. Bank Mandiri (Persero), Tbk. Cabang Cendrawasih ditinjau dari aspek kehadiran, dimana dari hasil analisis yang telah dilakukan menunjukkan bahwa tingkat kehadiran karyawan yang relatif tinggi karena karyawan tepat waktu masuk kantor karena PT. Bank Mandiri (Persero), Tbk. Cabang Cendrawasih menggunakan mesin Fringerprint yang sangat mudah dan praktis digunakan oleh karyawan, sehingga menunjang penyelesaian pekerjaan. Sedangkan hasil analisis mengenai kinerja karyawan pada PT. Bank Mandiri (Persero), Tbk. Cabang Cendrawasih ditinjau dari kemampuan kerjasama. Dimana dalam penelitian ini diperoleh temuan bahwa karyawan dalam melakukan pekerjaan selalu menjalin kerjasama dengan rekan kerja lainnya dan selain itu adanya tim kerja dalam penyelesaian pekerjaan serta adanya jalinan hubungan yang baik antara atasan dengan bawahan. Oleh karena itu maka disarankan kepada karyawan bagian marketing yang tidak mencapai target dalam melakukan pekerjaan, perlu meningkatkan pengeta-huan, keterampilan dalam melakukan pekerjaan. Memperhatikan aspek keteli-tian, kecermatan dalam menyelesaikan pekerjaan, memperhatikan pelaksanaan kerja yang tepat 
waktu dan lebih meningkatkan pemanfaatan waktu dalam menyelesaikan pekerjaan. Memberikan sanksi kepada karyawan yang sering terlambat guna dapat meningkatkan tingkat kehadiran kerja karyawan, serta meningkatkan kerjasama yang baik antara karyawan dengan rekan kerja lainnya dan antara karyawan dengan atasan sehingga terjalin komunikasi kerja yang baik.

\section{REFERENSI}

Agus Salim, 2006. Teori \& Paradigma Penelitian Sosial. Yogyakarta: Tiara Wacana

Ambar, Teguh, Sulistiyani dan Rosidah. 2013. Manajemen Sumber Daya Manusia, Konsep Teori dan Pengembangan Dalam Konteks Organisasi Publik, edisi kedua, cetakan pertama. Jakarta: Graha Ilmu.
Bangun, Wilson. 2012. Manajemen Sumber Daya Manusia, edisi pertama, cetakan pertama. Jakarta: Erlangga.

Hakim, Rahmat Budi. 2014. Manajemen dan Evaluasi Kinerja Karyawan, edisi pertama, cetakan pertama. Jakarta: Aswaja Pressindo.

Moeheriono. 2012. Pengukuran Kinerja Berbasis Kompetensi. Jakarta: Raja Grafindo Persada.

Sembiring Masana. 2012. Budaya Kinerja Organisasi (Perspektif Organisasi Pemerintah). Bandung: Fokus Media.

Sinambella, Poltak Lijan. 2012. Kinerja Karyawan Teori Pengukuran dan Implikasi, edisi pertama, cetakan pertama. Jakarta: Graha Ilmu.

Sugiyono. 2012. Memahami Penelitian Kualitatif. Bandung: Alfabeta.

Sujarweni. 2016. Kupas Tuntas: Pene-litian Akuntansi dengan SPSS, edisi lengkap, Jakarta: Pustaka Baru Press. 